\title{
In vitro Bioactivity, Bio-Corrosion Resistance and Antibacterial Property of Laser Cladded HA Coatings with Different Content of ZnO on Ti-6Al-4V Substrate
}

\author{
Baoping Hou ${ }^{a} \mathbb{D}$, Yangyang Liu ${ }^{a}$, Huibin Chen ${ }^{a}$, Yuling Yang ${ }^{a, b *}$ \\ ${ }^{a}$ School of Science, Northeastern University, Shenyang 110819, China \\ ${ }^{b}$ Key laboratory of laser application technology and equipment of Liaoning Province, Shenyang 110819, China
}

Received: November 20, 2018; Revised: June 24, 2019; Accepted: July 2, 2019

\begin{abstract}
$\mathrm{HA} / \mathrm{ZnO}$ coatings with varying content of $\mathrm{ZnO}$ were fabricated on Ti-6Al-4V substrate to enhance its bioactivity and antibacterial ability. The main phases are identified as $\mathrm{CaTiO}_{3}, \mathrm{Ca}_{3}\left(\mathrm{PO}_{4}\right)_{2}, \mathrm{ZnTiO}_{3}$ and CaO. The coatings with higher $\mathrm{ZnO}$ content presented smaller grain size, resulting in a higher surface free energy and better wettability. Consequently, the mineralization of the $\mathrm{ZnO} / \mathrm{HA}$ coatings, especially for the higher $\mathrm{ZnO}$ content samples were improved, indicating better enhanced in vitro bioactivity. The $\mathrm{ZnO}-\mathrm{HA}$ coated Ti-6Al-4V presented better corrosion resistance than bare Ti-6Al-4V substrate. Furthermore, better corrosion resistance was obtained by increasing $\mathrm{ZnO}$ content in the precursor. The antimicrobial ratio of all coatings was approximately $100 \%$, indicating the $\mathrm{ZnO}$ doped $\mathrm{HA}$ coatings presented excellent antibacterial ability.
\end{abstract}

Keywords: $\mathrm{ZnO} / \mathrm{HA}$ coating; wettability; in vitro bioactivity; bio-corrosion resistance; antibacterial ability.

\section{Introduction}

In recent years, titanium and its alloys are widely used for load bearing implants to heal skeletal defects caused due to old age, trauma, and injury. The advantages of titanium and its alloys include high strength to weight ratio, low modulus, and high biocompatibility ${ }^{1,2}$. However, as a potential scaffold biomaterial, providing excellent mechanical support for bone tissue growth is very important, meanwhile, it is also expected to provide enhanced bioactivity, bio-corrosion resistance, and antibacterial property on the surface ${ }^{3-5}$. Hydroxyapatite (HAp) owns excellent properties such as similarity to the inorganic components of human hard tissue, and good affinity for biological tissue ${ }^{6}$. In light of this, several researchers have synthesized HAp coatings on Ti-6Al-4V substrates to enhance its in vitro bioactivity and in vitro biocompatibility

${ }^{7,8}$. However, pure HAp coatings have relative low corrosion resistance in the biological environment and poor antibacterial property, which affects its long-term stability ${ }^{9}$.

For the purpose of improving biocompatibility, several researchers have synthesized HAp coating doped with trace amounts of useful metal ions such as $\mathrm{Zn}^{2+}, \mathrm{Sr}^{2+}, \mathrm{Mg}^{2+}, \mathrm{Na}^{+}$and $\mathrm{F}^{-}$. These ions exist in human bones, and have been found to be beneficial in regeneration of bone ${ }^{10-14}$. Among them, Zinc is found to be not only beneficial for bone regeneration, but also anti-inflammatory after implantation ${ }^{15,16}$. Corrosion resistance and biocompatibility of SrHAp/ $\mathrm{ZnO}$ coating fabricated by CED method has been investigated by Huang and his coauthors ${ }^{17}$, and the results showed that $\mathrm{ZnO}$ doped SrHAp coated Ti had a lower corrosion rate than the pure HAp-coated sample.
Different techniques, including Cathodic electro deposition (CED) ${ }^{17}$, sol-gel ${ }^{18}$, plasma-spraying ${ }^{19}$, and laser deposition ${ }^{20}$ procedures have been developed. Of these methods, laser cladding (LC) has gained extensive use due to its ability to achieve appropriate surface textures and surface chemistry and thereby improve the biocompatibility of metallic surfaces at the tissue-implant interface ${ }^{21-23}$. So far, the influences of different content of $\mathrm{ZnO}$ addition on the in vitro bioactivity, bio-corrosion resistance, and antibacterial property have not been extensively investigated.

In the current study, $\mathrm{ZnO} / \mathrm{HA}$ coatings were fabricated by laser cladding technology. The influence of $\mathrm{ZnO}$ content on the wettability, in vitro bioactivity, bio-corrosion resistance, and antibacterial ability of $\mathrm{ZnO}$ containing HA coating were investigated.

\section{Materials and Methods}

\subsection{Preparation of $\mathrm{ZnO} / \mathrm{HA}$ composite coating}

Commercially Ti-6Al-4V substrate coupons of $100 \times$ $100 \times 3 \mathrm{~mm}^{3}$ size were finished gradually with SiC papers of different grits $(600,800,1000$, and 1200), and sequentially rinsed with ethanol, acetone and distilled water in an ultrasonic cleaner to get a clean surface.

Commercially hydroxyapatite with chemical formula $\mathrm{Ca}_{10}\left(\mathrm{PO}_{4}\right)_{6}(\mathrm{OH})_{2}$ and $\mathrm{ZnO}$ powder, obtained from Sinopharm Group Shenyang Co. LTD, were used as the precursor materials. The HA and $\mathrm{ZnO}$ powder had a spherical morphology with a unimodal distribution in the range of $10-30 \mu \mathrm{m}$. 
The precursors (pure HAand $x$ wt. $\% \mathrm{ZnO}-\mathrm{HA}, x=5,10$, and 15 ) were mixed in a water based organic solvent polyvinyl alcohol. The mixed slurry was then sprayed onto the clean substrate coupons using an air pressurized spray gun. The sprayed coupons were then dried in an oven in which the temperature was kept at $100^{\circ} \mathrm{C}$ to remove the moisture. The thickness of $100 \mu \mathrm{m}$ of the precursor was maintained for all samples.

A JHM-1GY-700 pulsed Nd:YAG laser with a wavelength of $1064 \mathrm{~nm}$ was used to carry out laser cladding process. The maximum power of the laser is $700 \mathrm{~W}$. The laser parameters used in present work are listed in Table 1. A metallurgical bonding between the precursor and the substrate is achieved.

Table 1. Laser parameters used in present study

\begin{tabular}{ll}
\hline Pulse width $/ \mathrm{ms}$ & 1.5 \\
Pulse repetition rate/Hz & 30 \\
Laser scan speed $/ \mathrm{mm} \cdot \mathrm{s}^{-1}$ & 17 \\
Defocus distance $/ \mathrm{mm}$ & 20 \\
Single pulse energy/J & 2.5 \\
Average power/W & 75 \\
\hline
\end{tabular}

\subsection{Wetting and in vitro studies in $S B F$}

Before in vitro assays, wetting activity of the coatings was studied. Contact angle measurements were conducted by a static sessile drop technique using a CAM-Plus contact angle goniometer (Experimental Instrument Factory of HARKE, Beijing, China) equipped with video camera for imaging. With the aim of calculating surface energy, an apolar liquid (diiodomethane) and two polar liquids (distilled water and formamide) were used. In order to correlate the surface energy calculations to the mineralization behaviors of the samples, contact angles of the samples against a similar ionic composition to that of the human plasma, known as simulated body fluid (SBF) were measured. SBF solution as listed in Table 2 was prepared according to Ref. ${ }^{24}$. Six independent sets contact angles were measured for each sample to get the average value.

Table 2. Components and amount needed to prepare $1000 \mathrm{ml}$ of SBF

\begin{tabular}{lccc}
\hline Salt & Amount & Salt & Amount \\
\hline $\mathrm{NaCl}$ & $8.026 \mathrm{~g}$ & $\mathrm{CaCl}_{2}$ & $0.293 \mathrm{~g}$ \\
$\mathrm{NaHCO}_{3}$ & $0.352 \mathrm{~g}$ & $\mathrm{Na}_{2} \mathrm{SO}_{4}$ & $0.072 \mathrm{~g}$ \\
$\mathrm{KCl}$ & $0.225 \mathrm{~g}$ & $1 \mathrm{M} \mathrm{HCl}$ & $40 \mathrm{ml}$ \\
$\mathrm{K}_{2} \mathrm{HPO}_{4} .3 \mathrm{H}_{2} \mathrm{O}$ & $0.230 \mathrm{~g}$ & $\left(\mathrm{CH}_{2} \mathrm{OH}\right)_{3} \mathrm{CNH}_{2}$ & $6.063 \mathrm{~g}$ \\
$\mathrm{MgCl}_{2} \cdot 6 \mathrm{H}_{2} \mathrm{O}$ & $0.311 \mathrm{~g}$ & (Tris) & \\
\hline
\end{tabular}

In vitro studies were performed using the SBF solution. To study the bioactivity, the in vitro assays were carried out for a set of three samples from each processing condition.
The samples were soaked in $10 \mathrm{ml}$ of SBF solution in plastic containers. The solution was refreshed every $24 \mathrm{~h}$ to maintain a $\mathrm{pH}$ value of 7.4, and the temperature was maintained at $37{ }^{\circ} \mathrm{C}$ during the soaking course. After soaking 14 days, the samples were removed from the fluid and rinsed with distilled water, and then air dried for characterizing the sample surfaces by XRD and SEM-EDS.

\subsection{Coating characterization techniques}

A Rigaku-D/MAX-A X-ray diffractometer system was employed to analyze the phase structure of the coatings before and after SBF immersion. The radiation source was $\mathrm{Cu} \mathrm{Ka}$ radiation (wavelength, $0.15406 \mathrm{~nm}$ ), which was operated at $30 \mathrm{kV}$ and $20 \mathrm{~mA}$ in a $2 \theta$ range of $20-90^{\circ}$ using a step size of $0.02^{\circ}$. Addition of $\mathrm{ZnO}$ in the precursor was expected to produce refined grain structure. Hence, the grain size of the coated samples was calculated using the Scherrer formula ${ }^{25}$ :

$$
t=\frac{0.9 \lambda}{B \cos \theta_{B}}
$$

Here, $t$ is the grain size of a particular phase, $B$ is the broadening of diffraction line measured at half its maximum intensity (radians) at Bragg angle $\theta_{B}$, and $\lambda$ is the wavelength of $\mathrm{Cu} \mathrm{K} \alpha$ radiation $(0.15406 \mathrm{~nm})$. The peaks used for calculating grain size were chosen to avoid too much overlapping from different phases. In the above equation, the instrumental broadening is not taken into account as our interest was only to see the effect of $\mathrm{ZnO}$ content on the relative grain size.

After immersed in SBF, surface morphology and elements distribution of the samples was observed by means of scanning electronic microscope (SEM, SSX-550, Japan) instrument, which was operated at a volt of $15 \mathrm{kV}$.

\subsection{Potentiodynamic polarization test}

To evaluate the bio-corrosion resistance of the coatings, SBF solution prepared as listed in Table 2 was used. The corrosion behavior of the $\mathrm{ZnO} / \mathrm{HA}$ coatings in SBF solution at $37.0 \pm 0.5^{\circ} \mathrm{C}$ was investigated by means of potentiodynamic polarization test (electrochemical workstation, CHI660D, China). The platinum sheet was designed as auxiliary electrode, a saturated calomel electrode (SCE) as reference electrode and the samples as working electrode with an exposed surface area of $150 \mathrm{~mm}^{2}$. The polarization curves of the samples in $\mathrm{SBF}$ were obtained at a scan rate of $0.01 \mathrm{~V} / \mathrm{s}$. For the purpose of getting stable open circuit potential, the specimens were soaked in SBF solution for $1000 \mathrm{~s}$.

\subsection{Antibacterial activity tests}

The antibacterial activity of the $\mathrm{ZnO} / \mathrm{HA}$ coatings against the Gram-negative Staphylococcus aureus (S. aureus) was studied. The antibacterial activity determined using plate-counting method. Before the test, all samples and plates were sterilized using moist heat sterilization method in an autoclave at $120^{\circ} \mathrm{C}$ for $30 \mathrm{~min}$. 
After that, the samples were put into the Petri dishes, and $0.2 \mathrm{ml}$ bacteria culture with a concentration of $5.0 \sim 10.0 \times 10^{5}$ $\mathrm{CFU} / \mathrm{ml}$ was dripped onto the surfaces of each sample, and incubated for $24 \mathrm{~h}$ at $37^{\circ} \mathrm{C} \pm 1^{\circ} \mathrm{C}$. The blank plastic plate was used as a reference. The surviving bacterial colonies were counted after the incubation. The antibacterial rate $(\mathrm{R})$ were calculated according to Eq.(2) to evaluate the bacterial effect:

$$
R=\left(1-\frac{N}{N_{0}}\right) \times 100 \%
$$

Where $N_{0}$ and $N$ are the number of viable bacteria on a reference sample and $\mathrm{ZnO} / \mathrm{HA}$ coatings after antibacterial tests, respectively.

\section{Results and Discussions}

\subsection{Phase evolution}

Surface characterization of $\mathrm{ZnO} / \mathrm{HA}$ precursor-coated samples was carried out for several aspects, including phase analysis, crystallite size, and microstructure prior to wettability assays. The X-ray diffraction patterns corresponding to pure HA, 5 wt.\% ZnO-HA, 10 wt. \% ZnO-HA, and 15 wt. \% ZnO-HA precursor samples are illustrated in Fig. 1 (a) - (d), respectively. No major change in the types of phases was observed in the coatings with varying $\mathrm{ZnO}$ content. Besides Ti phase from the substrate, the new phases are identified as $\mathrm{CaTiO}_{3}$, $\mathrm{Ca}_{3}\left(\mathrm{PO}_{4}\right)_{2}, \mathrm{ZnTiO}_{3}$ and $\mathrm{CaO}$ after laser cladding process. It is noted that typical diffraction peaks for $\mathrm{HA}$ and $\mathrm{ZnO}$ from the original precursor were not found. This can be attributed the following possible primary and intermediate reactions between the material systems during laser processing. With the purpose of determining the possibility of the following reactions, the change of Gibbs free energy $(\Delta G)$ for each reaction was calculated according to thermodynamic theory and indicated in each equation.

$$
\begin{gathered}
\mathrm{Ca}_{10}\left(\mathrm{PO}_{4}\right)_{6}(\mathrm{OH})_{2}=3 \mathrm{Ca}_{3}\left(\mathrm{PO}_{4}\right)_{2}+\mathrm{CaO}+\mathrm{H}_{2} \mathrm{O} \uparrow \\
\left(\Delta G={ }_{-} 1333.75 \mathrm{~kJ} / \mathrm{mol}\right) \\
\mathrm{Ti}+\mathrm{O}_{2}=\mathrm{TiO}_{2} \quad(\Delta G=-864.09 \mathrm{~kJ} / \mathrm{mol}) \\
\mathrm{TiO}_{2}+\mathrm{CaO}=\mathrm{CaTiO}_{3} \quad(\Delta G=-80.90 \mathrm{~kJ} / \mathrm{mol}) \\
\mathrm{TiO}_{2}+\mathrm{ZnO}=\mathrm{ZnTiO}_{3} \quad(\Delta G=.516 .84 \mathrm{~kJ} / \mathrm{mol})
\end{gathered}
$$

The results of $\Delta \mathrm{G}$ of the above equations revealed that the primary reaction is the decomposition reaction of $\mathrm{HA}$, which results in the generation of $\mathrm{Ca}_{3}\left(\mathrm{PO}_{4}\right)_{2}$ and $\mathrm{CaO}$ as indicated in XRD results. The reaction process between $\mathrm{Ti}$ from the substrate and $\mathrm{O}_{2}$ gas from the air results in the generation of $\mathrm{TiO}_{2}$ (Eq.(4)). Accordingly, part of the $\mathrm{CaO}$ generated by decomposition of HA reacted with the $\mathrm{TiO}_{2}$ and led to the formation of $\mathrm{CaTiO}_{3}$ (Eq.(5)).
These reaction processes as shown in Eqs.(4) and (5) are likely to accelerate the resolving process of HA. That is the reason that no typical peaks for HA was detected by XRD in the coatings. As shown in Eq. (6), the reaction between $\mathrm{TiO}_{2}$ and $\mathrm{ZnO}$ results in the formation of $\mathrm{ZnTiO}_{3}$ as illustrated in Fig. 1.

The average grain size of the coatings was calculated using Scherrer formula as stated in Eq. 1. To avoid too much overlapping from different phases, the peaks for $\mathrm{Ca}_{3}\left(\mathrm{PO}_{4}\right)_{2}$ are used for calculating grain size. The results are presented in Fig. 1e. It is obvious that the grain size decreased with increasing of $\mathrm{ZnO}$ content in the coating. The grain size in $15 \mathrm{wt} . \% \mathrm{ZnO}-\mathrm{HA}$ coating is the smallest. It was reported that dopant was found to restrict possible grain growth consequently producing nanoscaled grains ${ }^{26}$. And it has been proven that the addition of $\mathrm{ZnO}$ facilitated the densification of forsterite ceramics ${ }^{27}$. In the recrystallization process, the porosities between grains were gradually removed due to the presence of zinc, and it was easier to form conglomerated grains, thus improved the degree of densification of hydroxyapatite coating. The result reveals the effect of $\mathrm{ZnO}$ addition on grain refinement.

\subsection{Wettability investigation}

For the purpose of studying wettability and in turn investigating in vitro bioactivity of $\mathrm{ZnO} / \mathrm{HA}$ covered samples, the surface energy components were calculated using the equations as stated in detail in our previous work $^{28}$. The surface energy $\left(\gamma_{S}\right)$ and contact angles against different solid are listed in Table 3. The variation of surface energy components (Lewis acid component $\gamma_{s}^{+}$, Lewis base component $\gamma_{s}^{-}$, apolar component $\gamma_{S}^{L W}$ and surface energy $\gamma_{S}$ ) as function of $\mathrm{ZnO}$ content in the precursors of laser cladded $\mathrm{ZnO} / \mathrm{HA}$ coatings are illustrated in Fig.2. Evidently, the dispersive component $\left(\gamma_{S}^{L W}\right)$ of pure HA coating is 44 $\mathrm{mJ} / \mathrm{m}^{2}$ and it varies slightly in the range of $37-40 \mathrm{~mJ} / \mathrm{m}^{2}$ with increasing weight percentage of $\mathrm{ZnO}$ in the precursor. The basic polar component $\gamma_{s}^{-}$of pure HA coating is $2.2 \mathrm{~mJ} /$ $\mathrm{m}^{2}$ and the acid polar component $\gamma_{s}^{+}$is $0.2 \mathrm{~mJ} / \mathrm{m}^{2}$. With the addition of $\mathrm{ZnO}$, the basic polar component $\gamma_{s}^{-}$decreased to $1.6 \mathrm{~mJ} / \mathrm{m}^{2}$ and then increased to $8.2 \mathrm{~mJ} / \mathrm{m}^{2}$ showing a law of decreasing first and then increasing, while the acid polar component $\gamma_{s}{ }^{+}$increased to $1.4 \mathrm{~mJ} / \mathrm{m}^{2}$ and then decreased to $0.2 \mathrm{~mJ} / \mathrm{m}^{2}$ showing a law of increasing first and then decreasing with increasing $\mathrm{ZnO}$ content from $5 \mathrm{wt} \%$ to $15 \mathrm{wt}$. \%. The surface free energy of pure HA coating is $45 \mathrm{~mJ} / \mathrm{m}^{2}$ and the 5 wt. $\% \mathrm{ZnO} / \mathrm{HA}$ coating and $10 \mathrm{wt} . \%$ $\mathrm{ZnO} / \mathrm{HA}$ coating have similar value of surface free energy $\gamma_{S}$ which is around $40 \mathrm{~mJ} / \mathrm{m}^{2}$, however, that of the $15 \mathrm{wt} \%$ $\mathrm{ZnO} / \mathrm{HA}$ coating increases to $50.2 \mathrm{~mJ} / \mathrm{m}^{2}$. As evidenced in Table 3, the laser processed $\mathrm{ZnO}$ substituted HA coatings result in higher surface energy compared to Ti-6Al-4V control. The possible reason for the variation in surface energy for these samples may be due to the grain size. 


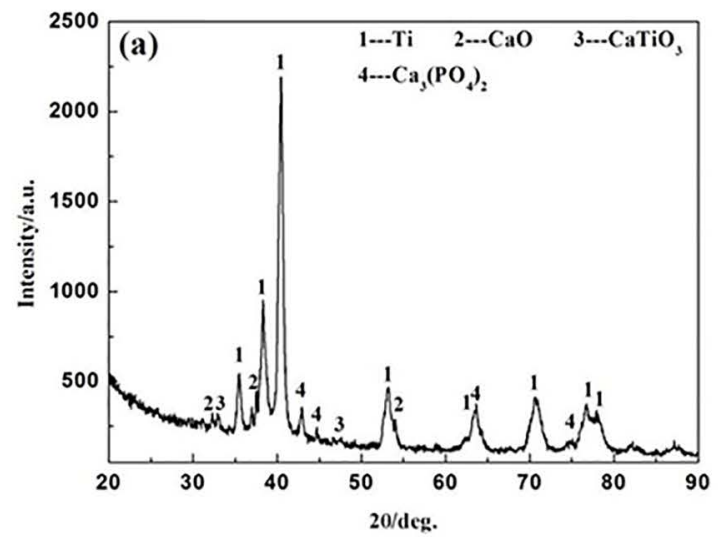

(a) pure HA coating

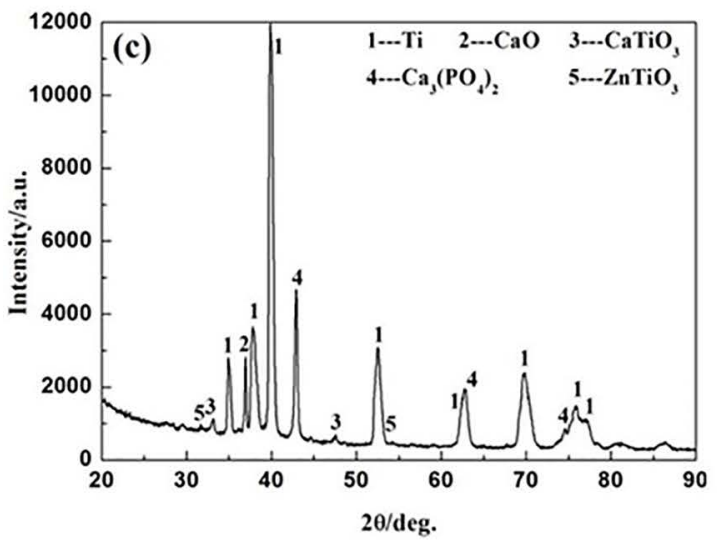

(c) 10 wt. $\% \mathrm{ZnO}-\mathrm{HA}$ coating

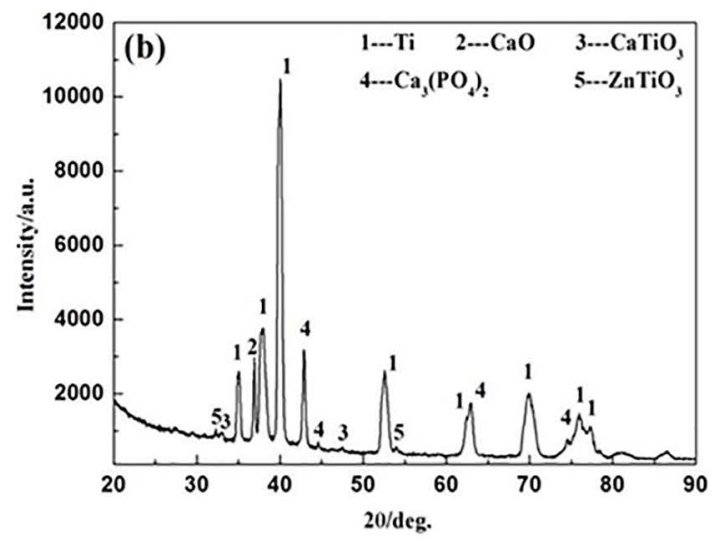

(b) 5 wt.\% $\mathrm{ZnO}-\mathrm{HA}$ coating

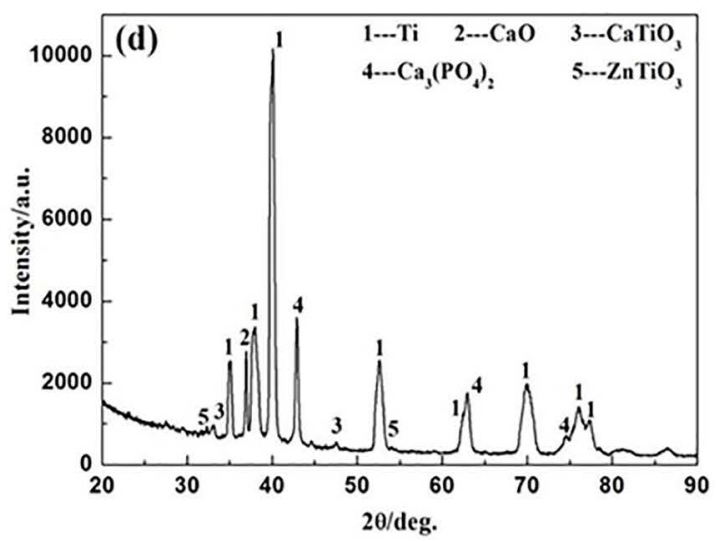

(d) 15 wt. $\%$ ZnO-HA coating

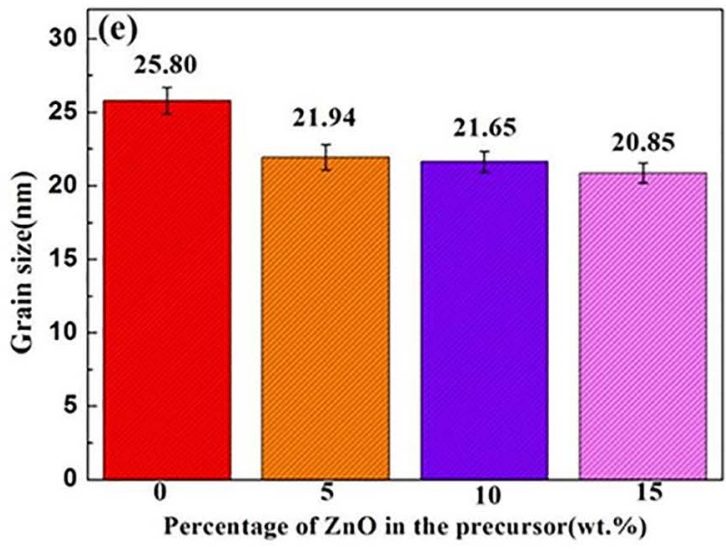

(e) grain size

Figure 1. XRD patterns of (a) pure HA coating, (b) 5 wt.\% ZnO-HA coating, (c) $10 \mathrm{wt} . \%$ ZnO-HA coating, (d) 15 wt.\% ZnO-HA coating after laser cladding procedure, and (e) grain size as a function of percentage of $\mathrm{ZnO}$ in the precursor

As described above (Fig. 1e), the average grain size of $15 \mathrm{wt} . \%$ $\mathrm{ZnO}-\mathrm{HA}$ sample is smaller than that of the pure HA coating, the 5 wt.\% ZnO-HA and the $10 \mathrm{wt} . \% \mathrm{ZnO}-\mathrm{HA}$ samples. It is well known that grain size strongly influences the grain boundary segregation. Therefore, more grain boundary grooves were formed with more content of $\mathrm{ZnO}$ addition leading to formation of more pinning of tripple lines. These pinned tripple lines act as open capillaries to reinforce wetting ${ }^{29}$. 
Table 3. Surface energy and contact angles against SBF solution of samples

\begin{tabular}{|c|c|c|c|c|c|}
\hline \multirow[b]{2}{*}{ Coatings } & \multicolumn{3}{|c|}{ Contact angle in different fluids } & \multirow{2}{*}{$\begin{array}{c}\text { Surface Energy } \gamma_{\mathrm{s}} \\
\left(\mathrm{mJ} \cdot \mathrm{m}^{-2}\right)\end{array}$} & \multirow{2}{*}{$\begin{array}{c}\text { Contact angle against } \\
\operatorname{SBF}\left({ }^{\circ}\right)\end{array}$} \\
\hline & Distilled water & Formamide & Dioiodomethane & & \\
\hline Pure HA & $86.4 \pm 4.2$ & $56.5 \pm 3.3$ & $30.2 \pm 5.0$ & $44.9 \pm 1.8$ & $64.4 \pm 2.1$ \\
\hline 5 wt. $\% \mathrm{ZnO} / \mathrm{HA}$ & $101.8 \pm 3.0$ & $82.6 \pm 3.1$ & $44.0 \pm 6.5$ & $40.7 \pm 3.9$ & $51.6 \pm 2.1$ \\
\hline 10 wt. $\% \mathrm{ZnO} / \mathrm{HA}$ & $89.5 \pm 3.2$ & $74.8 \pm 5.6$ & $46.0 \pm 2.5$ & $40.4 \pm 3.1$ & $51.3 \pm 1.8$ \\
\hline 15 wt. $\% \mathrm{ZnO} / \mathrm{HA}$ & $81.0 \pm 3.0$ & $64.5 \pm 4.4$ & $38.6 \pm 3.1$ & $50.2 \pm 2.4$ & $46.0 \pm 2.2$ \\
\hline Ti control & $82.6 \pm 0.1$ & $57.4 \pm 0.1$ & $53.0 \pm 0.4$ & $34.2 \pm 2.1$ & $63.7 \pm 0.3$ \\
\hline
\end{tabular}

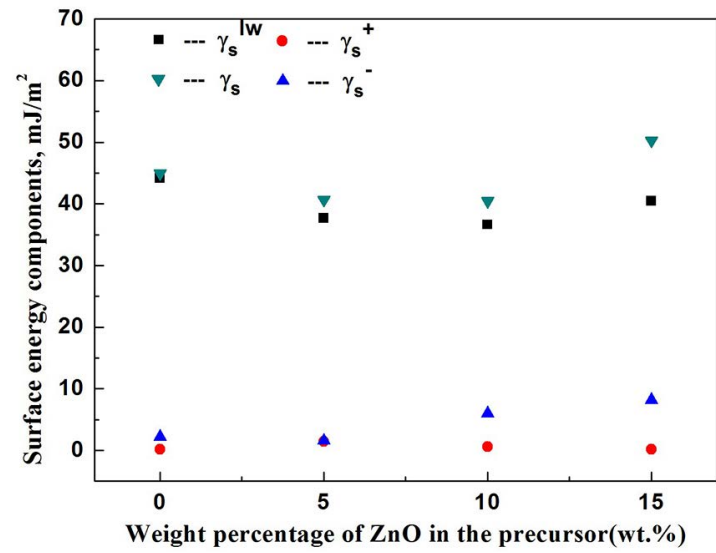

Figure 2. Surface energy as function of $\mathrm{ZnO}$ content in coating precursor

After a biomaterial being implanted into the biological system, the first and the foremost event is wetting. A material used in clinical practice must have appropriate wettability ${ }^{30}$. Wettability is perhaps one of the most important factors determining the quantity and quality of adsorbed proteins and the biocompatibility ${ }^{31,32}$. Hence, it is very essential to understand the wettability with SBF solution and wetting behavior of $\mathrm{ZnO} / \mathrm{HA}$ coated samples on the basis of surface free energy calculation. The static contact angle against SBF solution reflects directly the wettability of a material, therefore, the static contact angles of laser cladded $\mathrm{ZnO} / \mathrm{HA}$ coatings against SBF solution were performed and presented in Table 3 together with the corresponding light optical images of the liquid droplet shadow. As a reference, that of the Ti-6Al-4V control was also presented. The smaller the contact angle of a material against SBF solution, the better the wettability of the material is. In present work, the static contact angles of the $x$ wt. \% $\mathrm{ZnO} / \mathrm{HA}$ coatings against SBF solution are 51.6 $\pm 2.1^{\circ}, 51.3 \pm 1.8^{\circ}$, and $46.0 \pm 2.2^{\circ}$ corresponding to $x=5$,
10,15 , respectively, which are relatively smaller than that of the Ti-6Al-4V control $\left(63.7 \pm 0.3^{\circ}\right)$ and the pure HA coating $\left(64.4 \pm 2.1^{\circ}\right)$. The contact angle was lower to some extend by adding more $\mathrm{ZnO}$ in the coatings. This means that laser cladded $\mathrm{ZnO} / \mathrm{HA}$ coatings are more hydrophilic (higher surface free energy, and smaller contact angle), indicating the improved wettability. The static contact angle has been proven to be the most significant determinant of adhesion strength of cell and protein ${ }^{33}$. A higher surface energy results in a smaller static contact angle against SBF solution. This, in turn, will accelerate the adhesion and growth rate of the cells and protein. In the work by Zhang Li et al. ${ }^{34}$, it was postulated that the osteoblasts will preferentially adhere onto hydrophobic surfaces of biomaterials. Hence, it is expected that the enhanced hydrophilicity by presence of $\mathrm{ZnO} / \mathrm{HA}$ coatings will be favorable to the protein adsorption and osteoblast adhesion.

\subsection{In vitro behavior}

Studying the precipitation behavior of bone-like apatites in the SBF is one important way to investigate the in vitro bioactivity of the biomaterials. Fig.3a shows the XRD patterns of $\mathrm{ZnO}-\mathrm{HA}$ coatings after being soaked in SBF for 14 days. Typical apatite peaks were identified in three patterns. With increasing of $\mathrm{ZnO}$ content in the coating, the peaks for apatite became more and more clear, indicating that a higher weight percentage of $\mathrm{ZnO}$ in the precursor can accelerate apatite nucleation and growth after soaking in SBF. SEM images (Fig.3b-3e) presented the similar morphologies for all samples after being soaked in SBF for 14 days. The chemical compositions were analyzed using EDS and presented the figures as insets. The atom ratio of $\mathrm{Ca}$ to $\mathrm{P}$ was calculated from the EDS results. It is evident that the ratio of $\mathrm{Ca} / \mathrm{P}$ is $0.39,1.23,1.35$, and 1.75 , respectively, corresponding to pure $\mathrm{HA}, 5$ wt. $\% \mathrm{ZnO}-\mathrm{HA}$, 10 wt. $\%$ ZnO-HA, and 15 wt. \% ZnO-HA coated samples. 


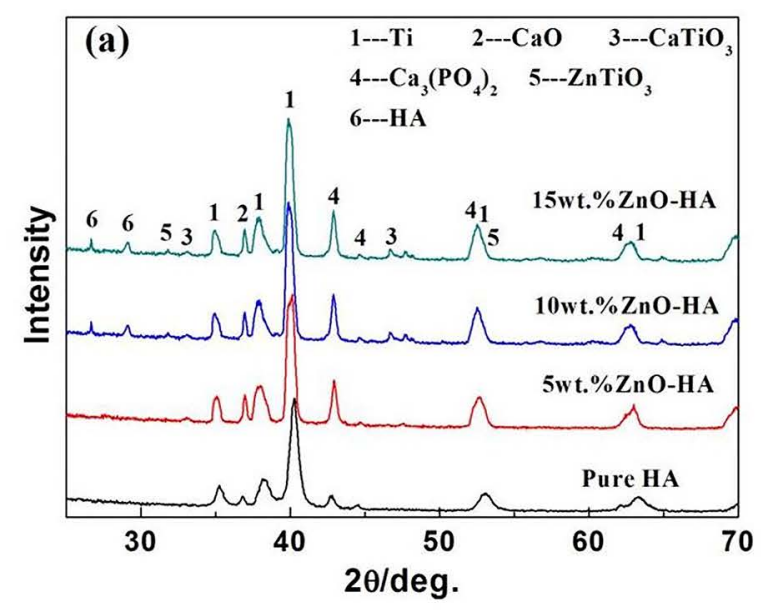

(a) XRD patterns

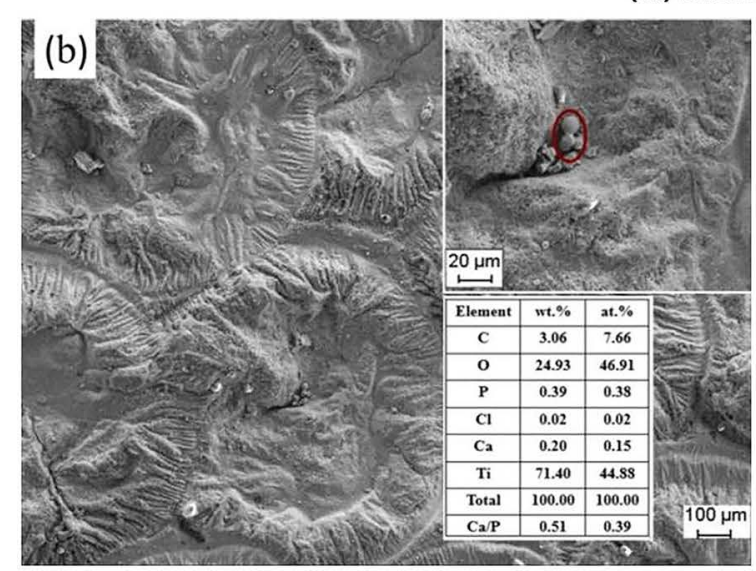

(b) pure HA coating

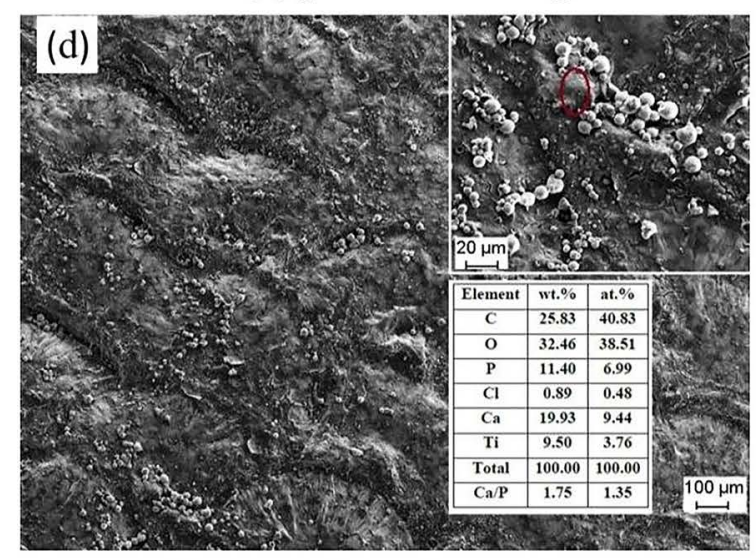

(d) 10 wt. $\%$ ZnO-HA coating

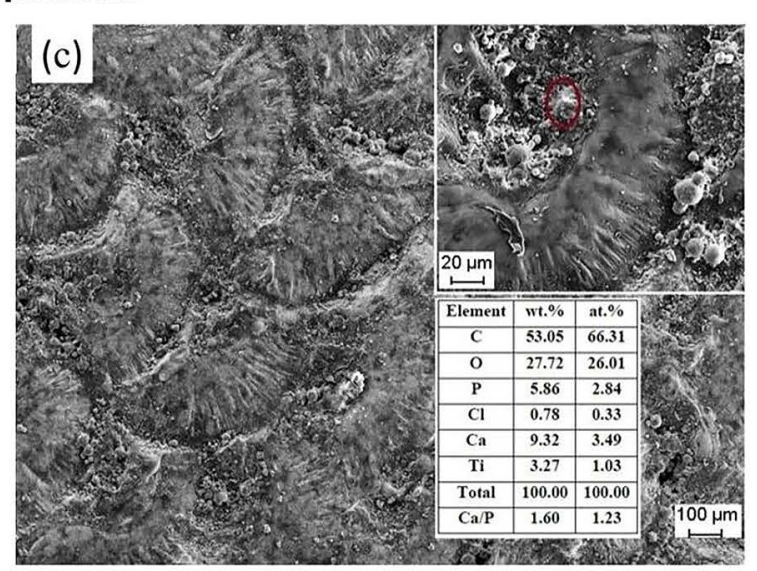

(c) 5 wt. $\%$ ZnO-HA coating

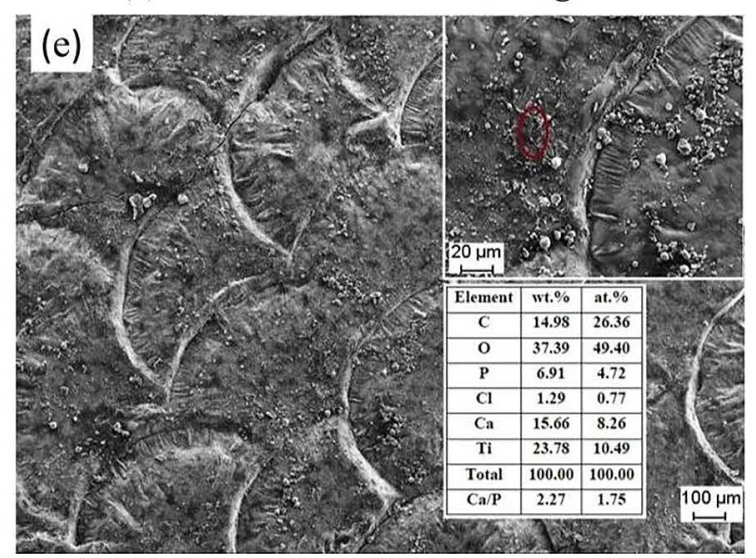

(e) 15 wt. $\%$ ZnO-HA coating

Figure 3. XRD patterns of the pure HA coating and $\mathrm{ZnO}-\mathrm{HA}$ coatings (a), SEM image of (b) pure HA coating, (c) 5 wt.\% $\mathrm{ZnO}-\mathrm{HA}$ coating, (d) $10 \mathrm{wt} . \% \mathrm{ZnO}-\mathrm{HA}$ coating, and (e) $15 \mathrm{wt} \%$ ZnO-HA coating after immersion in SBF for 14d . (The insets are SEM views with higher magnification and EDS analysis results)

The results indicated that the $\mathrm{ZnO}-\mathrm{HA}$ coating can successfully induce apatite nucleation and growth on Ti-6Al-4V surface. The atom ratio of $\mathrm{Ca}$ to $\mathrm{P}$ of the deposited layer on $15 \mathrm{wt} . \% \mathrm{ZnO}-\mathrm{HA}$ coating is close to that of $\operatorname{HCAP}(\mathrm{Ca} / \mathrm{P}=1.67)$, which is similar to the mineral composition of human bone, indicating that higher $\mathrm{ZnO}$ content in the precursor is more benefit for improving the mineralization after being soaked in SBF solution. 
This improvement in mineralization for the higher $\mathrm{ZnO}$ content samples can be attributed to the refining of the grain size and the improvement in wetting behavior as evidenced in Fig.1e and table 3. It is generally accepted that SBF assays may be useful to assess the capability to facilitate mineral composition of human bone ${ }^{35}$. The influence of $\mathrm{ZnO}$ dopant is more pronounced in stabilizing the HAp and inhibiting the decomposition of Hap. The presence of $\mathrm{Zn}^{2+}$ makes hydroxyapatite more aggregated and then easier to precipitate.

\subsection{Electrochemical corrosion results}

After being implanted in the human body, corrosion resistance of the material is one of the most important factors to influence the stability and lifetime of the implants. Hence, good corrosion resistance is very important for the implant devices besides wettability and bioactivity. The corrosion properties of Ti-6Al-4V control and $\mathrm{ZnO} / \mathrm{HA}$ coatings were investigated in a SBF environment.

The potentiodynamic scan of Ti-6Al-4V control and pure HA coating, $x$ wt. $\% \mathrm{ZnO} / \mathrm{HA}(x=5,10$, and 15) coatings in SBF solution at $37^{\circ} \mathrm{C}$ are illustrated in Fig. 4. Correspondingly, the corrosion potential $\left(E_{\text {corr }}\right)$ and corrosion current density $\left(I_{\text {corr }}\right)$ were calculated from the potentiodynamic curves based on the Tafel extrapolation method. The results of these corrosion parameters are listed in the inset of Fig. 4. Compared to Ti-6Al-4V control, the curves of $x$ wt.\% $\mathrm{ZnO} / \mathrm{HA}$ coatings shifted toward nobler $E_{\text {corr }}$ and lower $I_{\text {corr }}$ with increasing of $\mathrm{ZnO}$ content in the precursor. This shift reveals that the $\mathrm{ZnO}-\mathrm{HA}$ coatings increased the corrosion resistance of Ti-6Al-4V control. Meanwhile, better corrosion resistance was obtained by increasing $\mathrm{ZnO}$ content in precursor. The shift in $E_{\text {corr }}$ was also identified by the decrease in $I_{\text {corr }}$ as indicated in the inset in Fig. 4.

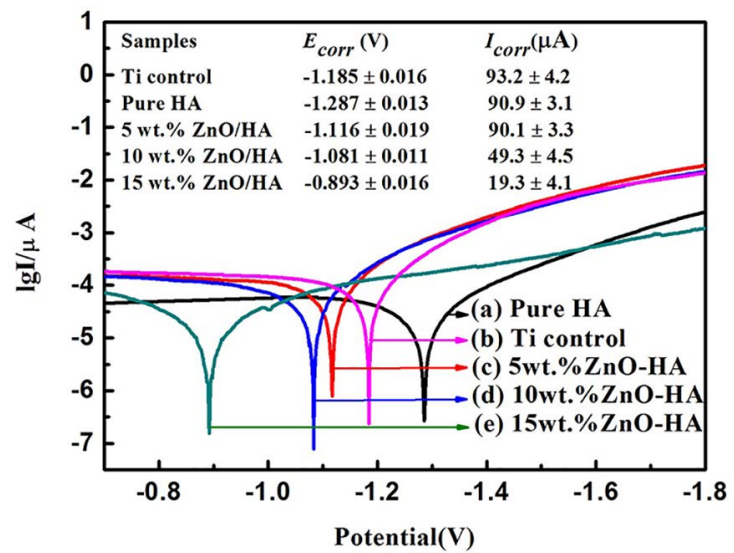

Figure 4. Polarization curves of Ti-6Al-4V and coating-covered samples in SBF
The corrosion rate is proportional to the $I_{\text {corr }}$ at a given potential, and materials with higher value of $I_{\text {corr }}$ will be more prone to corrosion ${ }^{36}$.

The results of Tafel slope values revealed that $I_{\text {corr }}$ of Ti6Al-4V control in SBF (approximately $93.2 \mu \mathrm{A}$ ) is higher than that of the $x$ wt. $\% \mathrm{ZnO}-\mathrm{HA}$ coatings $(90.9 \mu \mathrm{A}, 90.1 \mu \mathrm{A}$, $49.3 \mu \mathrm{A}$, and $19.3 \mu \mathrm{A}$ corresponding to $x=\underline{0,5}, 10$, and 15 , respectively). Hence, the results demonstrated that the 15 wt. $\% \mathrm{ZnO} / \mathrm{HA}$ coated sample is more corrosion resistant than uncoated Ti-6Al-4V and pure $\mathrm{HA}, 5$ wt. $\% \mathrm{ZnO} / \mathrm{HA}$ and 10 wt. $\% \mathrm{ZnO} / \mathrm{HA}$ coated sample in SBF solution. The coatings with higher $\mathrm{ZnO}$ content improved the protection ability of the Ti-6Al-4V substrate, and served as barrier layers against ionic diffusion. The study by $\mathrm{H}$. Farnoush ${ }^{37}$ and $\mathrm{Li}^{38}$ showed the same kind of results. The $\mathrm{ZnO} / \mathrm{HA}$ coatings, especially that with higher content of $\mathrm{ZnO}$ in the coating decreased the grain size as proven by the calculation results in Fig.1e. $\mathrm{ZnO}$ addition has a function of reducing crystallite size. The reduced grain size, in turn, had a significant function in promoting the activity of electrons at the grain boundaries ${ }^{39}$. The promotion of electrons' activity decreased $i_{\text {corr }}$ and thus improved corrosion protection. These results illustrated that the $\mathrm{ZnO} / \mathrm{HA}$ coatings, especially 15 wt. $\% \mathrm{ZnO}$-HA coating acted as a protective barrier layer to avoid ion diffusion and offer corrosion protection for the Ti-6Al-4V substrate.

\subsection{Antibacterial properties evaluation}

After 24-h incubation periods, the photographs of bacterial colonies were taken and antibacterial ratio was counted from the number of colonies. The results were shown in Fig. 5. It can be seen from the results that the pure HA coating sample shows an antibacterial ratio of about $20.83 \%$, however, the antibacterial ratio for all $\mathrm{ZnO} / \mathrm{HA}$ coatings is approximately $100 \%$. All $x$-wt. $\% \mathrm{ZnO} / \mathrm{HA}(x=5,10,15)$ coatings presented more excellent bactericidal ability against $S$. aureus compared to the reference sample and pure HA coating. As discussed earlier, the wettability and bio-corrosion resistance of the coatings with lower content of $\mathrm{ZnO}$ (5 wt.\% and $10 \mathrm{wt} . \%$ ) was not ideal compared to $15 \mathrm{wt} . \% \mathrm{ZnO} / \mathrm{HA}$ coating, however, regarding the antibacterial activity, the coating with lower content of $\mathrm{ZnO}$ is as better as the coating with higher content of $\mathrm{ZnO}$, indicating that lower content of $\mathrm{ZnO}$ can also present excellent antibacterial ability compared with the pure HA coating. The precipitated $\mathrm{Zn}^{2+}$ cause the dissolution of the cell contents by destroying the bacterial cell membrane, hindering the synthesis of the metabolic enzymes of the bacteria, destroying the genetic factors, thereby causing the bacteria to lose their biological activities. The experimental results show that the addition of $\mathrm{ZnO}$ greatly improved the antibacterial properties of the samples. 

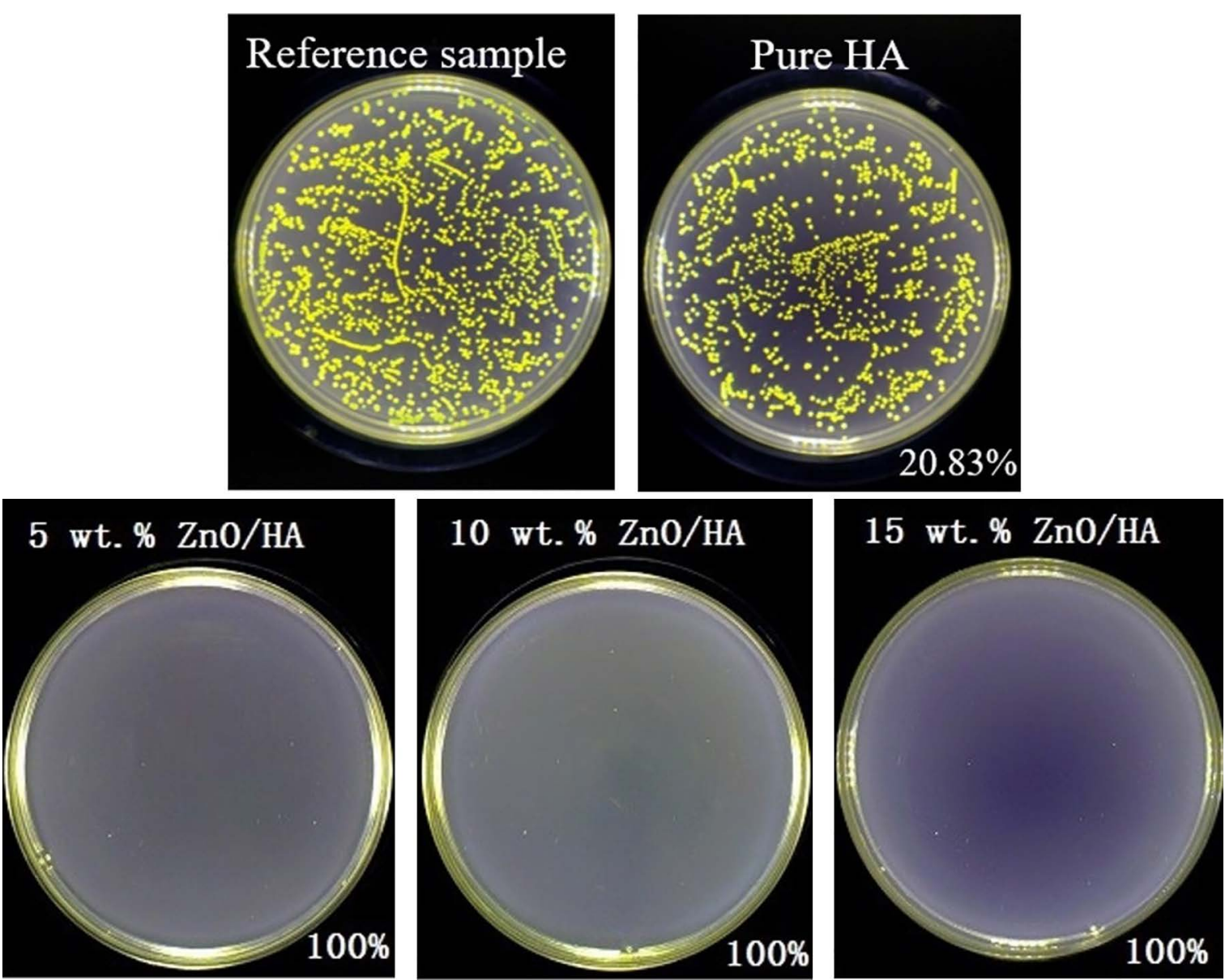

Figure 5. Antibacterial experiment photograph of the reference sample, pure $\mathrm{HA}$ and $\mathrm{ZnO} / \mathrm{HA}$ coatings

\section{Conclusions}

HA coatings substituted with different content of $\mathrm{ZnO}$ were fabricated on the surface of Ti-6Al-4V. The influence of $\mathrm{ZnO}$ content on the wettability, in vitro bioactivity and biocorrosion resistance was investigated. Studies of the coatings by XRD demonstrated that there is no major change in the types of phases with varying $\mathrm{ZnO}$ content in the precursor. Apart from the original phase from the substrate (Ti), the various other phases are identified as $\mathrm{CaTiO}_{3}, \mathrm{Ca}_{3}\left(\mathrm{PO}_{4}\right)_{2}$, $\mathrm{ZnTiO}_{3}$ and $\mathrm{CaO}$ due to the decomposition reaction of $\mathrm{HA}$ and reactions between the new phases in laser melt pooling.

The grain size decreased with increasing of $\mathrm{ZnO}$ content in the coating. The results reveal that the addition of $\mathrm{ZnO}$ play an important role in grain refinement. The grain refinement, in turn, results in the increasing of surface free energy and decreasing of contact angle of coatings against SBF solution. The contact angle of the coating with higher content of $\mathrm{ZnO}$ against SBF solution was lower than the coatings with lower content of $\mathrm{ZnO}$. Laser cladded $\mathrm{ZnO} / \mathrm{HA}$ coatings are more hydrophilic (higher surface free energy, and smaller contact angle), indicating the more excellent wettability.
As a result of refining of the grain size and the improvement in wetting behavior, the mineralization and in turn the in vitro bioactivity of the $\mathrm{ZnO} / \mathrm{HA}$ coatings, especially for the higher $\mathrm{ZnO}$ content samples was enhanced.

The Tafel curves of the coatings shifted toward nobler $E_{\text {corr }}$ and lower $I_{\text {corr }}$ with increasing of $\mathrm{ZnO}$ content in the precursor, revealing that the $\mathrm{ZnO}-\mathrm{HA}$ coatings increased the corrosion resistance of Ti-6Al-4V control. Better corrosion resistance was obtained by increasing $\mathrm{ZnO}$ content in precursor. The antimicrobial ratio of all $\mathrm{ZnO} / \mathrm{HA}$ coatings was approximately $100 \%$, indicating the $\mathrm{ZnO}$ doped HA coatings presented excellent antibacterial ability.

\section{Acknowledgements}

The work described in this paper is financially supported by the Natural Science Foundation of Liaoning province (No. 201602264), the $12^{\text {th }}$ University Student's Innovation Training Project (No. 180027), and the Fundamental Research Funds for the Central Universities (N180705002). 


\section{References}

1. Gopi D, Karthika A, Sekar M, Kavitha L, Pramod R, Dwivedi J. Development of lotus-like hydroxyapatite coating on HELCDEB treated titanium by pulsed electrodeposition. Materials Letters. 2013;105:216-219.

2. Gopi D, Shinyjoy E, Sekar M, Surendiran M, Kavitha L, Sampath Kumar TS. Development of carbon nanotubes reinforced hydroxyapatite composite coatings on titanium by electrodeposition method. Corrosion Science. 2013;73:321-330.

3. Foppiano S, Marshall SJ, Marshall GW, Saiz E, Tomsia AP. The influence of novel bioactive glasses on in vitro osteoblast behavior. Journal of Biomedical Materials Research. Part A. 2004;71(2):242-249.

4. Bosetti M, Cannas M. The effect of bioactive glasses on bone marrow stromal cells differentiation. Biomaterials. 2005;26(18):3873-3879.

5. Hattar S, Asselin A, Greenspan D, Oboeuf M, Berdal A, Sautier JM. Potential of biomimetic surfaces to promote in vitro osteoblastlike cell differentiation. Biomaterials. 2005;26(8):839-848.

6. Okabe Y, Kurihara S, Yajima T, Seki Y, Nakamura I, Takano I. Formation of super-hydrophilic surface of hydroxyapatite by ion implantation and plasma treatment. Surface and Coatings Technology. 2005;196(1-3):303-306.

7. Lopez-Heredia MA, Legeay G, Gaillard C, Layrolle P. Radio frequency plasma treatments on titanium for enhancement of bioactivity. Acta Biomaterialia. 2008;4(6):1953-1962.

8. Pecheva EV, Pramatarova LD, Maitz MF, Pham MT, Kondyurin AV. Kinetics of hydroxyapatite deposition on solid substrates modified by sequential implantation of $\mathrm{Ca}$ and $\mathrm{P}$ ions: Part I. FTIR and Raman spectroscopy study. Applied Surface Science. 2004;235(1-2):176-181.

9. Qiu DL, Yang LJ, Yin YS, Wang AP. Preparation and characterization of hydroxyapatite/titania composite coating on NiTi alloy by electrochemical deposition. Surface and Coatings Technology. 2011;205(10):3280-3284.

10. Ikeuchi M, Ito A, Dohi Y, Ohgushi H, Shimaoka H, Yonemasu $\mathrm{K}$, et al. Osteogenic differentiation of cultured rat and human bone marrow cells on the surface of zinc-releasing calcium phosphate ceramics. Journal of Biomedical Materials Research. Part A. 2003;67(4):1115-1122.

11. Pereiro I, Rodríguez-Valencia C, Serra C, Solla EL, Serra J, González P. Pulsed laser deposition of strontium-substituted hydroxyapatite coatings. Applied Surface Science. 2012;258(23):9192-9197.

12. Bodhak S, Bose S, Bandyopadhyay A. Bone cell-material interactions on metal-ion doped polarized hydroxyapatite. Materials Science and Engineering: C. 2011;31(4):755-761.

13. Bir F, Khireddine H, Touati A, Sidane D, Yala S, Oudadesse H. Electrochemical depositions of fluorohydroxyapatite doped by $\mathrm{Cu}^{2+}, \mathrm{Zn}^{2+}, \mathrm{Ag}^{+}$on stainless steel substrates. Applied Surface Science. 2012;258(18):7021-7030.
14. Zreiqat H, Howlett CR, Zannettino A, Evans P, Schulze-Tanzil G, Knabe C, et al. Mechanisms of magnesium-stimulated adhesion of osteoblastic cells to commonly used orthopaedic implants. Journal of Biomedical Materials Research. 2002;62(2):175-184.

15. Li X, Sogo Y, Ito A, Mutsuzaki H, Ochiai N, Kobayashi T, et al. The optimum zinc content in set calcium phosphate cement for promoting bone formation in vivo. Materials Science and Engineering: C. 2009;29(3):969-975.

16. Velard F, Laurent-Maquin D, Braux J, Guillaume C, Bouthors S, Jallot $\mathrm{E}$, et al. The effect of zinc on hydroxyapatite-mediated activation of human polymorphonuclear neutrophils and bone implant-associated acute inflammation. Biomaterials. 2010;31(8):2001-2009.

17. Huang Y, Zeng HJ, Wang XX, Wang DS. Corrosion resistance and biocompatibility of $\mathrm{SrHAp} / \mathrm{ZnO}$ composite implant coating on titanium. Applied Surface Science. 2014;290:353-358.

18. Milev A, Kannangara GSK, Ben-Nissan B. Morphological stability of hydroxyapatite precursor. Materials Letters. 2003;57(13-14):1960-1965.

19. Liu X, Ding C, Wang Z. Apatite formed on the surface of plasma-sprayed wollastonite coating immersed in simulated body fluid. Biomaterials. 2001;22(14):2007-2012.

20. Bolbasov EN, Lapin IN, Svetlichnyi VA, Lenivtseva YD, Malashicheva A, Malashichev Y, et al. The formation of calcium phosphate coatings by pulse laser deposition on the surface of polymeric ferroelectric. Applied Surface Science. 2015;349:420-429.

21. Yang YL, Serpersu K, He W, Paital SR, Dahotre NB. Osteoblast interaction with laser cladded $\mathrm{HA}$ and $\mathrm{SiO}_{2}$-HA coatings on Ti-6Al4V. Materials Science and Engineering: C. 2011;31(8):1643-1652.

22. Paital SR, Cao Z, He W, Dahotre NB. Wetting effects on in vitro bioactivity and in vitro biocompatibility of laser micro-textured Ca-P coating. Biofabrication. 2010;2(2):025001.

23. Paital SR, He W, Dahotre NB. Laser pulse dependent micro textured calcium phosphate coatings for improved wettability and cell compatibility. Journal of Materials Science. Materials in Medicine. 2010;21(7):2187-2200.

24. Oyane A, Kim HM, Furuya T, Kokubo T, Miyazaki T, Nakamura T. Preparation and assessment of revised simulated body fluids. Journal of Biomedical Materials Research. Part A. 2003;65(2):188-195.

25. Cullity BD. Elements of X-ray Diffraction. $2^{\text {nd }}$ ed. Reading: Addison-Wesley; 1978. 284 p.

26. Mukhopadhyay A, Basu B. Consolidation-microstructure-property relationships in bulk nanoceramics and ceramic nanocomposites: a review. International Materials Reviews. 2007;52(5):257-288.

27. Tan CY, Tan YM, Ramesh S, Yap BK. Effect of ZnO addition on the purity and densification of forsterite ceramic. IOP Conference Series: Materials Science and Engineering. 2017;206:012051.

28. Yang YL, Paital SR, Dahotre NB. Wetting and in vitro bioactivity of laser processed $\mathrm{CaP}$ coating with presence and variation of $\mathrm{SiO}_{2}$ on Ti-6Al-4V. Materials Technology: Advanced Performance Materials. 2010;25(3-4):137-142. 
29. Eustathopoulos N, Nicholas MG, Drevet B, eds. Wettability at High Temperatures. Volume 3. $2^{\text {nd }}$ ed. New York: Pergamon Press; 1999.

30. Yoshikawa M, Hayami S, Toda T. In vivo estimation of calcium phosphate cements containing chondroitin sulfate in subcutis. Materials Science and Engineering: C. 2002;20(1-2):135-141.

31. Tangpasuthadol V, Pongchaisirikul N, Hoven VP. Surface modification of chitosan films: Effects of hydrophobicity on protein adsorption. Carbohydrate Research. 2003;338(9):937-942.

32. Zanchetta P, Guezennec J. Surface thermodynamics of osteoblasts: relation between hydrophobicity and bone active biomaterials. Colloids and Surfaces B: Biointerfaces. 2001;22(4):301-307.

33. Zhang M, Li XH, Gong YD, Zhao NM, Zhang XF. Properties and biocompatibility of chitosan films modified by blending with PEG. Biomaterials. 2002;23(13):2641-2648.

34. Zhang L, Li YB, Zuo Y, Wu L, Jansen JA. In vitro and in vivo evaluation on the bioactivity of $\mathrm{ZnO}$ containing nanohydroxyapatite/chitosan cement. Journal of Biomedical Materials Research. Part A. 2010;93(1):269-279.
35. Zhang LL, Li HJ, Li KZ, Fu QG, Zhang YL, Liu SJ. A Na and Si co-substituted carbonated hydroxyapatite coating for carbon nanotubes coated carbon/carbon composites. Ceramics International. 2014;40(8 Pt B):13123-13130.

36. Yusoff MFM, Kadir MRA, Iqbal N, Hassan MA, Hussain R. Dipcoating of poly( $\varepsilon$-caprolactone)/hydroxyapatite composite coating on Ti6Al4V for enhanced corrosion protection. Surface and Coatings Technology. 2014;245:102-107.

37. Farnoush H, Mohandesi JA, Fatmehsari DH, Moztarzadeh F. Modification of electrophoretically deposited nano-hydroxyapatite coatings by wire brushing on Ti-6Al-4V substrates. Ceramics International. 2012;38(6):4885-4893.

38. Li HJ, Zhao XN, Cao S, Li KZ, Chen MD, Xu ZW, et al. Nadoped hydroxyapatite coating on carbon/carbon composites: Preparation, in vitro bioactivity and biocompatibility. Applied Surface Science. 2012;263:163-173.

39. Huang Y, Ding QQ, Han SG, Yan YJ, Pang XF. Characterisation, corrosion resistance and in vitro bioactivity of manganesedoped hydroxyapatite films electrodeposited on titanium. Journal of Materials Science: Materials in Medicine. 2013;24(8):1853-1864 